\title{
Insulin allergy can be successfully managed by a systematic approach
}

\author{
Maija Bruun Haastrup ${ }^{1 *}$, Jan Erik Henriksen², Charlotte Gotthard Mortz ${ }^{3}$ and Carsten Bindslev-Jensen ${ }^{3}$
}

\begin{abstract}
Background: Type I insulin allergy can be a challenging condition, and there is no international consensus on how to establish the diagnosis. Measurement of specific lgE and skin testing have been cornerstones in the diagnostic work-up. However, these tests have limitations, mainly lack of correlation between test results and clinical findings. At the Allergy Centre, Odense University Hospital, patients with suspected insulin allergy have been evaluated since 2003. The aim of this study was to establish a systematic approach to diagnose and treat patients with insulin allergy.

Methods: The study was conducted retrospectively by retrieving data from the Allergy Centre database on patients with suspected insulin allergy evaluated from 2003 to 2017. The examination comprised a comprehensive medical history, specific lgE against insulin and intracutaneous tests (ICT) with different insulins.

Results: A total of 144 patients were examined on suspicion of insulin allergy of which 110 had negative specific lgE in serum. Of the remaining 34 patients, 33 had ICT performed; 2 had negative ICTs, while 31 had one or more positive ICT. All 34 patients had mild symptoms, and 4 could obtain symptom relief with antihistamines or local steroids, 9 could be managed with oral antidiabetics, and 7 were switched to other insulins. The final 14 patients were offered an insulin pump because of reactions to many different insulins, many positive ICTs, unmanageable diabetes, young age and compliance, or convenience.
\end{abstract}

Conclusion: Insulin allergy can be managed by a systematic approach, and symptom relief is obtainable in most patients.

Keywords: Insulin, Allergy, lgE, Intracutaneous test

\section{Background}

Insulin allergy affects $0.1-3 \%$ of insulin-treated diabetics $[1,2]$ and causes symptoms ranging from localized itching and rash to life-threatening anaphylaxis [3-5]. The IgE-mediated (type I) reaction is by far the most common, but type III and type IV reactions have been reported as well [1, 6-9].

The diagnosis is based on past and present symptoms and signs, together with skin tests and specific immunoglobulin E (IgE) measurement in serum. Skin prick test (SPT) and intracutaneous test (ICT) have traditionally been used in the evaluation of these patients. However, the reliability of the results from skin tests has been

\footnotetext{
*Correspondence: mhaastrup@health.sdu.dk

${ }^{1}$ Department of Clinical Biochemistry and Pharmacology, Odense University Hospital, Odense, Denmark

Full list of author information is available at the end of the article
}

questionable for a number of reasons including false-negative tests, and non-specific reactions as well as reactions to additives (e.g. protamine sulfate) [3, 5, 6, 8-10]. Measurement of specific $\operatorname{IgE}(\mathrm{sIgE})$ is another cornerstone in the diagnosis, but this method has limitations as well, mainly due to poor correlation between clinical findings and elevated IgE levels $[3,6]$. Consequently, there is no consensus on the correct method for diagnosing insulin allergy yet, though one was suggested by Jacquier et al. in 2013 [11], based on three patient cases. The authors suggested the use of measurement of total IgE, insulinspecific IgE, and anti-insulin antibodies (IgG) in addition to SPT or ICT.

The treatment of insulin allergy is often straightforward. For many patients it is possible to switch insulin preparation or to avoid insulin use by managing their diabetes through diet or oral antidiabetics and/or injections

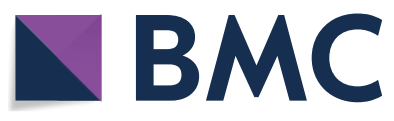

(c) The Author(s) 2018. This article is distributed under the terms of the Creative Commons Attribution 4.0 International License (http://creativecommons.org/licenses/by/4.0/), which permits unrestricted use, distribution, and reproduction in any medium, provided you give appropriate credit to the original author(s) and the source, provide a link to the Creative Commons license, and indicate if changes were made. The Creative Commons Public Domain Dedication waiver (http://creativecommons.org/ publicdomain/zero/1.0/) applies to the data made available in this article, unless otherwise stated. 
with glucagon-like peptide 1 (GLP1) analogue treatment. Some patients, however, are insulin dependent and experience symptoms during treatment with many different insulins. These patients are difficult to treat and require a more comprehensive approach, sometimes including desensitization $[3,9,12]$.

At the Allergy Centre at Odense University Hospital patients with insulin allergy have been diagnosed and treated since 2003. The aim of the present study was to summarize the diagnostic findings and to present a systematic approach for the examination and treatment of these patients.

\section{Methods}

This study was conducted retrospectively and included data from the Allergy Centre database, ACbase, on patients seen at the Odense Research Center for Anaphylaxis (ORCA), Allergy Centre at Odense University Hospital from 2003 through March 2017 with suspicion of insulin allergy. Since 2010 the Allergy Centre in Odense has been the only place in Denmark to evaluate patients suspected of insulin allergy in collaboration with the Department of Endocrinology, Odense University Hospital.

The examination comprised a comprehensive medical history (type of diabetes, duration and severity of symptoms, prior treatment etc.), measurement of specific IgE against human, bovine, and porcine insulin and-where appropriate-also ICT with different insulins.

Specific IgE measurement (ImmunoCAP) against human, bovine and porcine insulin was performed by Thermo Fisher, Uppsala Sweden. Values above $0.35 \mathrm{kIU} / \mathrm{L}$ were considered positive.

Intracutaneous tests were performed by injecting $20-50 \mu \mathrm{L}$ of the different insulins in the concentration $5 \mathrm{IE} / \mathrm{mL}$, and reactions were considered positive if the wheal size diameter was $3 \mathrm{~mm}$ larger than the initial bleb. ICTs were read after $20 \mathrm{~min}$, according to guidelines from the European Network on Drug Allergy (ENDA) [13]. As controls, skin prick tests were performed with histamine $10 \mathrm{mg} / \mathrm{mL}$ (ALK-Abello, Denmark) as the positive control and isotonic $\mathrm{NaCl}$ as the negative control.

The insulins available for the test varied over time, and some of the first patients seen $(n=3)$ were only tested with a selection of the available insulin types, based on the clinician's judgment. The majority, however, were tested with the full panel of insulins, which included rapid acting human insulin (Humulin Regular ${ }^{\circledR}$, Insuman Rapid $^{\circledR}$, Actrapid $^{\circledR}$ ), rapid acting analogue insulin lispro $\left(\right.$ Humalog $\left.^{\circledR}\right)$, and insulin aspart $\left(\right.$ NovoRapid $\left.^{\circledR}\right)$, and intermediate acting isophane human insulin (Humulin $\mathrm{NPH}^{\circledR}$, Insulatard ${ }^{\circledR}$, both containing protamine), and long acting analogue insulin: Insulin glargine (Lantus ${ }^{\circledR}$ ), and insulin detemir $\left(\right.$ Levemir $\left.^{\circledR}\right)$. Most recently, the following additions have been made to the panel: Toujeo ${ }^{\circledR}$, Abasaglar ${ }^{\circledR}$ (both insulin glargine), Tresiba (insulin deglucec), NovoMix ${ }^{\circledR}$ (insulin aspart with added protamine), and Apidra $^{\circledR}$ (insulin glulisine).

SPT with insulin was initially a part of the examination but was abandoned due to the poor sensitivity and specificity of the test. Basophil histamine release (HR test) was performed in a few patients but not systematically. Consequently, the results of SPT and HR test are omitted.

The patients-or in the case of children, their parentsgave informed consent to store their data in the ACbase. All data for this study were collected after approval from the Danish Data Protection Agency (17/11270).

\section{Results}

A flow chart of the protocol for the examination of suspected insulin allergy is presented in Fig. 1.

A total of 144 patients with suspected insulin allergy were seen at the Allergy Centre, Odense University Hospital, from 2003 through March 2017. Of these, 34 had positive sIgE for insulin and were included in the study while 110 had negative sIgE for insulin and were judged non-allergic (type I). Among those deemed non-allergic 71 had an ICT performed with 12 having one or more positive ICTs. Another 5 were positive to protamine sulfate but none of the included insulins. ICTs were performed in these patients before the results of the IgE measurements were available. A positive ICT in a patient with a negative IgE may be an unspecific reaction, a reaction to an additive, or a delayed reaction reflecting a type IV allergy.

The 34 patients with positive sIgE were categorised according to symptom severity. All 34 patients had local symptoms only (pruritus, nodules, localised dermatitis and infiltration at injection sites). Patients, whose symptoms could be alleviated by antihistamines or local steroids $(\mathrm{n}=4)$, and patients, who could be managed by other antidiabetic medications than insulin $(n=9)$, were treated accordingly.

In 33 of the 34 patients with positive sIgE, ICT was performed. One was not tested due to age (12 years). Two of the 33 patients exhibited negative ICTs, however one of the two was only tested for one specific insulin preparation (Apidra ${ }^{\circledR}$ ) due to age (9 years).

The demographics and test results of the 21 insulin dependent patients with positive $\operatorname{sIgE}$ are presented in Table 1 (data not shown for the remaining 13 patients because the symptoms of these patients could be managed without insulin). Of the 20 patients tested with ICTs 19 were ICT-positive for at least one insulin preparation (range 1-9). The ICT-negative patient was the 9-year old 


\section{Patients suspected of insulin allergy $(n=144)$}

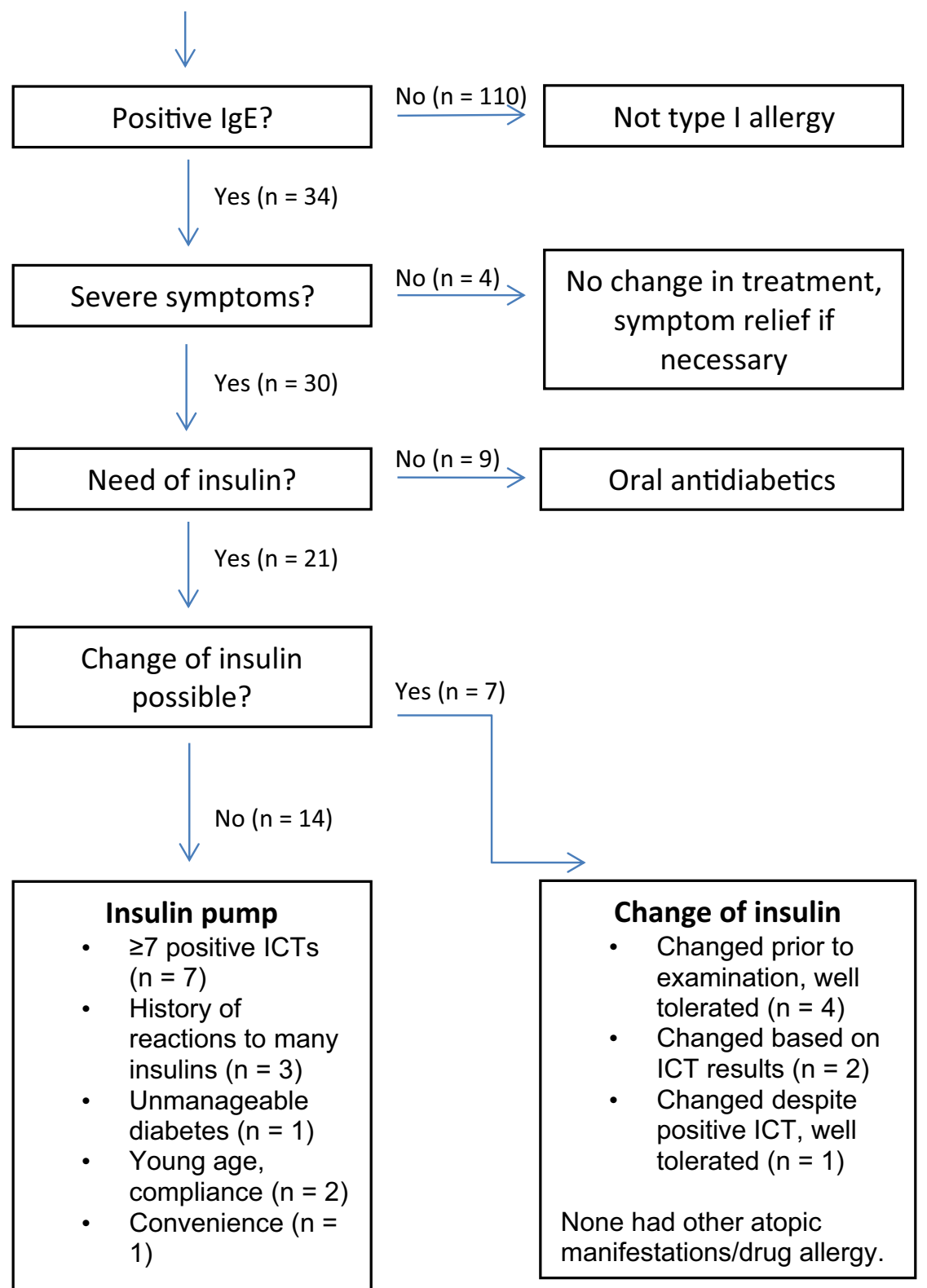

Eight of 14 had other atopic manifestations/drug allergy.

Fig. 1 Flow chart of the procotol for examination of suspected insulin allergy

girl, who was only tested for one insulin preparation by ICT.

In the 21 insulin dependent patients a change in treatment regimen was necessary due to symptom severity.
Where possible $(n=7)$, a switch was made to another insulin preparation. Of these 7 patients, a well-tolerated switch had already been made prior to evaluation at the Allergy Centre in 4, and consequently, no further 
Table 1 Demographics and test results

\begin{tabular}{|c|c|c|c|c|c|c|c|c|c|c|c|c|c|c|c|c|}
\hline \multirow[t]{2}{*}{ ID } & \multirow[t]{2}{*}{ Sex } & \multirow[t]{2}{*}{ Age } & \multirow[t]{2}{*}{ DM type } & \multicolumn{3}{|l|}{ slgE } & \multicolumn{9}{|l|}{ ICT } & \multirow[b]{2}{*}{ J } \\
\hline & & & & Porcine & Bovine & Human & $A$ & B & $C$ & D & $E$ & $F$ & G & $\mathrm{H}$ & $I$ & \\
\hline 1 & $\mathrm{~F}$ & 60 & $\|$ & 2.1 & 1.3 & 1.6 & - & + & - & - & - & - & - & - & - & N/D \\
\hline 2 & F & 55 & $\|$ & 0.6 & 0.4 & 0.5 & + & N/A & N/A & N/A & N/A & N/A & N/A & + & + & N/D \\
\hline 3 & $\mathrm{~F}$ & 14 & । & 2.6 & 2.0 & 1.9 & + & + & - & - & + & + & $\mathrm{N} / \mathrm{D}$ & + & + & N/D \\
\hline 4 & F & 59 & $\|$ & 7.1 & 5.9 & 6.2 & + & + & + & + & + & + & + & N/D & N/D & N/D \\
\hline 5 & $\mathrm{~F}$ & 41 & ॥ & 1.5 & 1.1 & 1.8 & + & + & + & + & + & + & + & + & + & N/D \\
\hline 6 & M & 55 & ॥ & 22.8 & 18.5 & 22.8 & + & + & + & + & + & + & + & + & + & N/D \\
\hline 7 & M & 67 & $\|$ & 0.6 & 0.4 & 0.5 & + & + & + & + & + & + & + & + & - & N/D \\
\hline 8 & $\mathrm{~F}$ & 47 & $\|$ & 8.9 & 7.9 & 7.7 & + & + & + & + & + & + & + & N/D & - & N/D \\
\hline 9 & M & 37 & $\|$ & 0.4 & $<0.35$ & 0.4 & - & + & - & - & - & - & - & - & + & N/D \\
\hline 10 & F & 36 & I & 1.3 & 1.0 & 1.0 & - & - & - & - & - & - & + & - & - & N/D \\
\hline 11 & $\mathrm{~F}$ & 37 & ॥ & 1.7 & 1.3 & 1.6 & + & + & + & + & + & + & + & + & + & N/D \\
\hline 12 & F & 12 & I & 0.4 & $<0.35$ & $<0.35$ & N/D & N/D & N/D & N/D & N/D & N/D & N/D & N/D & N/D & N/D \\
\hline 13 & $\mathrm{~F}$ & 9 & I & 0.5 & $<0.35$ & 0.4 & N/D & N/D & N/D & N/D & N/D & N/D & N/D & N/D & N/D & - \\
\hline 14 & $\mathrm{~F}$ & 54 & I & 0.1 & $<0.35$ & 0.4 & - & - & N/D & - & - & - & - & + & - & N/D \\
\hline 15 & $\mathrm{~F}$ & 64 & I & 2.9 & 2.4 & 2.7 & + & + & + & N/A & N/A & N/A & N/A & + & + & N/D \\
\hline 16 & F & 46 & ॥ & 2.5 & 2.2 & 2.2 & + & + & + & N/D & N/D & N/D & N/D & + & N/D & N/D \\
\hline 17 & $M$ & 56 & $\|$ & 2.4 & 2.1 & 1.8 & + & + & + & + & + & + & + & + & + & N/D \\
\hline 18 & $M$ & 55 & I & 0.4 & $<0.35$ & 0.4 & - & - & - & - & - & - & + & - & - & N/D \\
\hline 19 & $M$ & 30 & I & 3.4 & 2.5 & 2.2 & + & + & + & - & - & + & + & - & + & N/D \\
\hline 20 & $M$ & 57 & I & 0.6 & 0.6 & 0.7 & + & - & + & - & + & - & - & - & - & N/D \\
\hline 21 & $M$ & 79 & ॥ & 15.0 & 15.2 & 13.2 & N/D & + & - & + & + & + & + & + & + & N/D \\
\hline
\end{tabular}

Patients 1-14 were given an insulin pump, 15-21 changed insulin preparation. All symptoms were local. N/A result not available in the database, $N / D$ not done. $\lg \mathrm{E}>0.35$ was considered positive

$A$ humulin regular, $B$ insuman rapid, $C$ actrapid, $D$ humulin $N P H, E$ insulatard, $F$ lantus, $G$ levemir, $H$ novorapid, $I$ humalog, $J$ apidra

treatment adjustment was needed. Two were successfully switched to a different insulin, based on negative ICT. The last patient in this group was switched to an insulin despite a positive ICT for this particular insulin. The switch, however, was well-tolerated.

The final group of patients $(n=14)$ was offered treatment with an insulin pump in collaboration with the Department of Endocrinology, Odense University Hospital. Seven of these patients exhibited $\geq 7$ positive ICTs. Three additional patients had histories of reactions to many different insulins. One patient's diabetes was unmanageable, two were offered an insulin pump because of young age and compliance and one due to convenience.

Of the 14 patients given an insulin pump, eight had other atopic manifestations or drug allergy (challengeverified penicillin allergy, atopic dermatitis, asthma, hay fever, contact allergy, and urticaria). None of the 7 patients, whose insulins were changed, had other atopic manifestations/other drug allergies. The groups did not differ with regards to age, sex, diabetes type, sIgE levels or number of positive ICTs, see Table 2.
Table 2 Comparison of patient characteristics and test results between the two groups

\begin{tabular}{lll}
\hline & Insulin pump $(\mathbf{n = 1 4 )}$ & Other insulin $(\mathbf{n = 7})$ \\
\hline Sex (M:F) & $3: 11$ & $5: 2$ \\
Age (years) & $41.6(9-67)$ & $55.3(30-79)$ \\
Diabetes type (I:II) & $4: 10$ & $4: 3$ \\
Other atopic manifesta- & $8: 6$ & $0: 7$ \\
$\quad$ tions/drug allergy & & \\
(Y:N) & & $5(1-9)$ \\
No. of positive ICTs & $5.9(0-9)$ & $3.31(0.4-13.2)$ \\
$\lg E_{\text {human }}(\mathrm{klU} / \mathrm{L})$ & $4.07(0.4-22.8)$ & $4.17(0.6-15.2)$ \\
$\operatorname{lgE}_{\text {bovine }}(\mathrm{kIU} / \mathrm{L})$ & $4.76(0.4-18.5)$ & $3.89(0.4-15.0)$ \\
$\operatorname{lgE}_{\text {porcine }}(\mathrm{kIU} / \mathrm{L})$ & $3.64(0.4-22.8)$ &
\end{tabular}

Overview of sex distribution and type l/type II diabetes ratio, average age, slgE (human, bovine and porcine) and number of positive ICTs (range). Other atopic manifestations/drug allergy: Two patients had challenge-proven penicillin allergy, 2 asthma, 2 hay fever, 1 urticaria and 1 atopic dermatitis and contact allergy. Only positive slgE values are included

\section{Discussion}

The majority of the published literature concerning insulin allergy has been case reports or small case series. This study is the largest of its kind so far. 
Of a total of 144 patients suspected of insulin allergy only 34 (24\%) had positive sIgE, which is comparable to a study by Bodtger and Wittrup from 2005 [14], where the diagnosis was established in 9 of 22 patients (41\%). The diagnostic work-up in this study consisted, however, only of intracutaneous testing.

We focused mainly on specific IgE measurement for the diagnosis of insulin allergy, because this in vitro test has a high negative predictive value $[10,15]$, whereas elevated levels are not necessarily indicative of allergy and are thus of limited value without a thorough medical history and supplementary skin testing $[9,16]$.

Skin tests, particularly SPT, have poor sensitivity but high specificity, and the negative predictive value of ICT is high $[5,9,15]$. These tests can be helpful in distinguishing between insulins with and without the capability of causing clinical reactions when choosing future treatment for a given patient.

A total of 13 of the 34 patients (38\%) with an insulin allergy diagnosis in our study could be managed without a change in treatment or with oral antidiabetics. Another 7 were switched to a different insulin preparation, and the final 14 were desensitised with continuous subcutaneous infusions through an insulin pump. This has been described in several reports as an option for patients with an indispensable need for insulin who cannot be managed by switching to another insulin preparation $[8$, $17-22]$.

The most recent addition to the treatment options for these patients is omalizumab. This has been successful in two of three case reports so far and may represent an interesting alternative for patients whose symptoms cannot otherwise be managed [23-25].

None of the patients in the present study had a history of systemic reactions to insulin. Therefore, other treatment options than desensitization were chosen whenever possible. An insulin desensitization was mainly performed in those with many positive ICTs and a history of reactions to many different insulin preparations. In case of a history of anaphylaxis in insulin dependent patients, desensitization should always be performed.

Type 2 diabetics potentially represent a twofold challenge given that their endogenous insulin production decreases with time which most likely will cause a return of the symptoms of insulin allergy, when the patients can no longer be managed with oral antidiabetics.

\section{Conclusion}

Insulin allergy is a challenging condition, but can most often be managed by a systematic approach, and symptom relief is obtainable in most if not all patients.

\section{Abbreviations}

ENDA: European Network on Drug Allergy; ICT: intracutaneous test; IgE: immunoglobulin E; ORCA: Odense Research Center for Anaphylaxis; slgE: specific IgE; SPT: skin prick test.

\section{Authors' contributions}

$\mathrm{MBH}$ analysed the patient data. MBH, CGM, and CBJ interpreted the patient data. All authors were major contributors in writing the manuscript. All authors read and approved the final manuscript.

\section{Author details \\ 1 Department of Clinical Biochemistry and Pharmacology, Odense University Hospital, Odense, Denmark. ${ }^{2}$ Steno Diabetes Center Odense, Odense Uni- versity Hospital, Odense, Denmark. ${ }^{3}$ Odense Research Center for Anaphylaxis (ORCA), Department of Dermatology and Allergy Centre, Odense University Hospital, Odense, Denmark.}

\section{Acknowledgements}

The authors would like to thank Ulla Johannessen and Esben Eller for assistance in retrieving data from the database.

\section{Competing interests}

The authors declare that they have no competing interests.

\section{Availability of data and materials}

The datasets used during the current study are available from the corresponding author on reasonable request.

\section{Consent for publication}

The patients — or in the case of children, their parents — gave informed consent to store their data in the ACbase for use in future research in allergic diseases after approval of the Danish Data Protection Agency.

\section{Ethics approval and content to participate}

The patients - or in the case of children, their parents - gave informed consent to store their data in the ACbase (License No. 2008-58-0035). All data for this study were collected after approval from the Danish Data Protection Agency (17/11270).

Funding

No funding was supplied for this study.

\section{Publisher's Note}

Springer Nature remains neutral with regard to jurisdictional claims in published maps and institutional affiliations.

Received: 13 June 2018 Accepted: 22 August 2018

Published online: 25 September 2018

\section{References}

1. Radermecker RP, Scheen AJ. Allergy reactions to insulin: effects of continuous subcutaneous insulin infusion and insulin analogues. Diabetes Metab Res Rev. 2007;23(5):348-55.

2. Fineberg SE, Huang J, Brunelle R, Gulliya KS, Anderson JH Jr. Effect of long-term exposure to insulin lispro on the induction of antibody response in patients with type 1 or type 2 diabetes. Diabetes Care. 2003;26(1):89-96.

3. Heinzerling L, Raile K, Rochlitz H, Zuberbier T, Worm M. Insulin allergy: clinical manifestations and management strategies. Allergy. 2008:63(2):148-55.

4. Borch JE, Andersen KE, Bindslev-Jensen C. Cutaneous adverse drug reactions seen at a university hospital department of dermatology. Acta Derm Venereol. 2006;86(6):523-7.

5. Lee AY, Chey WY, Choi J, Jeon JS. Insulin-induced drug eruptions and reliability of skin tests. Acta Derm Venereol. 2002;82(2):114-7.

6. deShazo RD, Mather P, Grant W, Carrington D, Frentz JM, Lueg M, Lauritano AA, Falholt K. Evaluation of patients with local reactions to insulin with skin tests and in vitro techniques. Diabetes Care. 1987;10(3):330-6. 
7. Wittrup M, Pildal J, Rasmussen AK, Skov BG, Petersen J, MandrupPoulsen TR. Systemic and local allergy to human insulin. Ugeskr Laeger. 2003;165(21):2207-8

8. Ghazavi MK, Johnston GA. Insulin allergy. Clin Dermatol. 2011;29(3):300-5.

9. Akinci B, Yener S, Bayraktar F, Yesil S. Allergic reactions to human insulin: a review of current knowledge and treatment options. Endocrine. 2010;37(1):33-9.

10. Brockow $\mathrm{K}$, et al. Skin test concentrations for systemically administered drugs - an ENDA/EAACI Drug Allergy Interest Group position paper. Allergy. 2013;68(6):702-12.

11. Jacquier J, Chik CL, Senior PA. A practical, clinical approach to the assessment and management of suspected insulin allergy. Diabet Med. 2013;30(8):977-85.

12. Heinzerling L. Insulin allergy. Diabet Med. 2013;30(8):891-2.

13. Brockow K, et al. General considerations for skin test procedures in the diagnosis of drug hypersensitivity. Allergy. 2002;57(1):45-51.

14. Bodtger $U$, Wittrup M. A rational clinical approach to suspected insulin allergy: status after five years and 22 cases. Diabet Med. 2005;22(1):102-6.

15. Joint Task Force on Practice Parameters, American Academy of Allergy, Asthma and Immunology, American College of Allergy, Asthma and Immunology, Joint Council of Allergy, Asthma and Immunology. Drug allergy: an updated practice parameter. Ann Allergy Asthma Immunol. 2010;105(4):259-73.

16. Demoly P, Adkinson NF, Brockow K, Castells M, Chiriac AM, Greenberger PA, Khan DA, Lang DM, Park HS, Pichler W, Sanchez-Borges M, Shiohara T, Thong BY. International consensus on drug allergy. Allergy. 2014:69(4):420-37.

17. Valentini U, Cimino A, Rocca L, Pelizzari R, Rotondi A, Tosoni C. CSII in management of insulin allergy. Diabetes Care. 1988;11(1):97-8.
18. Pratt EJ, Miles P, Kerr D. Localized insulin allergy treated with continuous subcutaneous insulin. Diabet Med. 2001;18(6):515-6.

19. Sola-Gazagnes A, Pecquet C, Radermecker R, Piétri L, Elgrably F, Slama $G$, Sélam JL. Successful treatment of insulin allergy in a type 1 diabetic patient by means of constant subcutaneous pump infusion of insulin. Diabetes Care. 2003;26(10):2961-2.

20. Matheu V, Perez E, Hernández M, Díaz E, Darias R, González A, García JC, Sánchez I, Feliciano L, Caballero A, de la Torre F. Insulin allergy and resistance successfully treated by desensitisation with Aspart insulin. Clin Mol Allergy. 2005;23(3):16.

21. Zhang L, Zhang M, Liu YY, Hu M, Zhou X, Luo Y. Successful treatment with continuous subcutaneous insulin infusion for allergy to human insulin and its analogs. Diabetes Res Clin Pract. 2011;94(1):e1-2.

22. Fujikawa T, Imbe H, Date M, Go Y, Kitaoka H. Severe insulin allergy successfully treated with continuous subcutaneous insulin infusion. Diabetes Res Clin Pract. 2012;97(2):e31-3.

23. Yong PF, Malik R, Arif S, Peakman M, Amiel S, Ibrahim MA, Gough A. Rituximab and omalizumab in severe, refractory insulin allergy. N Engl I Med. 2009;360(10):1045-7.

24. Cavelti-Weder C, Muggli B, Keller C, Babians-Brunner A, Biason-Lauber A Donath MY, Schmid-Grendelmeier P. Successful use of omalizumab in an inadequately controlled type 2 diabetic patient with severe insulin allergy. Diabetes Care. 2012;35(6):e41.

25. Koroscil T, Kagzi Y, Zacharias D. Failure of multiple therapies in the treatment of a type 1 diabetic patient with insulin allergy: a case report. Endocr Pract. 2011;17(1):91-4.
Ready to submit your research? Choose BMC and benefit from:

- fast, convenient online submission

- thorough peer review by experienced researchers in your field

- rapid publication on acceptance

- support for research data, including large and complex data types

- gold Open Access which fosters wider collaboration and increased citations

- maximum visibility for your research: over 100M website views per year

At $\mathrm{BMC}$, research is always in progress.

Learn more biomedcentral.com/submissions 